\title{
Towards Greater Understanding Of Ecolabel Effects: The Role Of Country Of Origin
}

Sihem Dekhili, HuManiS (EA 1347) EM Strasbourg Business School, France Mohamed Akli Achabou, IPAG Business School, France

\begin{abstract}
This research explores the country of origin effect on the evaluation of ecolabelled products. Findings from experimentation indicate that the mention of a country of origin with favorable image in terms of sustainable development has a neutral effect on the evaluation of an ecolabelled product. However, the indication of a country with a negative image affects the product' evaluation negatively.
\end{abstract}

Keywords: Consumer Behaviour; Country of Origin; European Ecolabel; Sustainable Development

\section{INTRODUCTION}

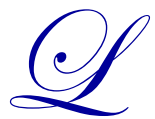

et's consider the following scenario: a French firm manufactures eco-products in different European countries, and has just been awarded the 'European ecolabel' certification for all of its products. Its managers then discuss the benefits of including information on the country of origin as well as the ecolabel. Do equivalent European products featuring the same ecolabel reflect the same ecological quality in the eyes of the consumer? Or is there a country of origin effect? This was the question that guided our research.

Few studies have attempted to integrate the notion of country of origin with respect to ecological considerations, and have tended instead to focus on the environmental footprint generated by transportation of the product in question (Smith et al., 2005).

The impact of country of origin is one of the oldest and most persistent topics in international marketing. The concept of country of origin image (Nagashima, 1970) was largely defined on the basis of political and economic factors, and traits linked to product functionality and the workers' manufacturing skills (Han, 1989), ignoring the environmental and social dimensions. However, there is strong evidence that different countries project different ecological images. Despite the efforts of the European Commission with regard to standardisation of ecological practices through the introduction of common labels, EU member countries may have different objectives in terms of increasing demand for ecolabelled products (Thøgersen, Haugaard, \& Olesen, 2010). Also, for a same ecolabel, the levels of requirements may vary from one country to another (Lozano, Blanco, \& Rey-Maquieira, 2010). This led us to pose the question of whether the country of origin's ecological image contributes to strengthening (or reducing) the impact of the ecolabel. Our study takes an original perspective by questioning whether the ecological image of the country of origin has an impact on the assessment of the products that should, a priori, present the same ecological qualities as those reflected by the European ecolabel.

We begin our article with a review of the literature. We then describe the methodology, before turning to the case study and discussion that focuses on washing up liquid. Finally, we look at the implications and limitations of our study.

${ }^{1}$ The European ecolabel, created in 1992, is the only officially recognised green label in all the member states and in Switzerland. It has become increasingly common in recent years, increasing from 6 exploitation licences in 1996 to 1357 in 2011 (European Commission, 2012). 


\section{REVIEW OF THE LITERATURE}

Ecolabels were developed to inform consumers of a product's conformity with environmental and social standards, and to simplify the decision-making process (Thøgersen, Jørgensen, \& Sandager, 2012). The literature has analysed their impact on preference, and generally concluded that consumers are ready to pay more for products with an ecolabel (Harris \& Freeman, 2008). On the other hand, several authors have also noted that preference for ecolabels varies depending on the product categories (Onozaka \& McFadden, 2011). The issue of consumer trust in ecolabels has frequently been covered in the literature. Some studies (Thøgersen, Haugaard, \& Olesen, 2010) have suggested that, despite their official character, labels are insufficient to reassure consumers due to the number and differences in ecolabels found on the market.

Despite the voluntary of the European Commission to standardize sustainable practices through the creation of common certifications, the classification of the World Economic Forum (2013) shows a strong heterogeneity between European countries in terms of environmental and social efforts. Some countries, such as Switzerland (ranked $\mathrm{n}^{\circ} 1$ ), make considerable efforts regarding sustainable development, while others, like Spain and Italy (ranked $n^{\circ} 36$ and $n^{\circ} 42$ respectively) seem to be insensitive to this issue. Yet, adding the geographical origin could help consumers to avoid products from countries with a negative reputation regarding sustainable development (Reuber \& Fischer, 2011). In this research, we propose to investigate how the ecological image of the country of origin impacts the assessment of an ecolabelled product.

Because of the importance of consumers' socio-demographic and behavioral characteristics (D'Souza et al. 2007), variables such as gender, education level, and income will be tested. Also, we will explore the effect of familiarity with ecological products and trust towards the country of origin.

\section{METHODOLOGY}

In this study, we set up an experiment with a control group of the pre-test-post-test type (Shadish et al., 2002). We chose the case of washing up liquid (WUL). Two washing up liquids that differed slightly in terms of perfume (thyme and rosemary) were investigated. Switzerland was selected as a European country with a favourable ecological image, and Spain was considered as a country associated with a negative ecological image.

The experiment protocol adopted three phases (blind assessment; information about the ecolabel; information about the ecolabel and the country of origin). Product assessment was considered through the bias of two key variables: intention to purchase and willingness to pay (WTP).

A total sample of 153 consumers took part in the study. Recruitment was through ads, ${ }^{2}$ and students were rejected. To vary the sample, the experiments took place in two French cities: Strasbourg $(n=99)$ and Paris $(n=54)$. The respondents were randomly put into one of two groups, a test group $(\mathrm{n}=106)$ and a control group $(\mathrm{n}=47)$. A within-subject manipulation was adopted, and a total of 19 sessions (from 7 to 13 participants) were organised between May and August 2012, lasting around 40 minutes each. The participants each received an Ecolabelled cleaning product at the end of the session.

\section{RESULTS}

Analysis of the perceived differences between the two countries tested (test-t on paired samples) showed that the respondents present the same degree of familiarity $\left(\mathrm{M}_{\text {Switzerland }}=4.13\right.$ and $\mathrm{M}_{\text {Spain }}=4.10$; ns $)$ and proximity $\left(\mathrm{M}_{\text {Switzerland }}=3.83\right.$ and $\mathrm{M}_{\text {Spain }}=3.48$; ns $)$ with the two countries, and like them $\left(\mathrm{M}_{\text {Switzerland }}=4.58\right.$ and $\mathrm{M}_{\text {Spain }}=4.85$; ns) in similar fashion. (Table 1).

The respondents associate a more favourable ecological image to Switzerland in comparison with Spain

\footnotetext{
${ }^{2}$ The ads were posted in different institutions (universities, companies...) and on websites.
} 
Table 1: Scores of Country of Origin Dimensions Regarding to Sustainable Development

\begin{tabular}{lc}
\hline \multicolumn{1}{c}{ Dimensions } & Mean \\
\hline Production of Ecological Products & 2.71 \\
$\quad$ Spain & 4.92 \\
$\quad$ Switzerland & 2.77 \\
Environnemental Protection & 5.35 \\
$\quad$ Spain & 4.01 \\
$\quad$ Switzerland & 3.49 \\
Equal Opportunities to All Employees & 2.97 \\
$\quad$ Spain & 5.03 \\
Switzerland & 2.83 \\
Fair Wages & 5.19 \\
Spain & 2.85 \\
Switzerland & 4.56 \\
Workplace Security & 2.93 \\
$\quad$ Spain & 5.13 \\
Switzerland &
\end{tabular}

The ANOVA results on consumers' intention to purchase and maximum price to pay indicate that Spain had a significant direct effect on intention to purchase with both the washing up liquids tested (WUL thyme: $F(1,152)$ $\left.=5.59, \mathrm{p}<.05 ; \mathrm{WUL}_{\text {Rosemary }}: \mathrm{F}(1,152)=8.79, \mathrm{p}<.05\right)$. The contrasts enabled us to confirm that adding the mention 'Spain' to the label contributed to a drop in intention to purchase for an ecolabelled product compared to the situation when the country is not mentioned. The difference in average reflected $9 \%$ less to willingness to pay for $\mathrm{WUL}_{\text {thyme }}\left(8 \%\right.$ in the case of $\left.\mathrm{WUL}_{\text {Rosemary }}\right)$ when Spain was indicated.

Mentioning Switzerland, on the other hand, did not seem to impact the intention to purchase a washing up liquid or the maximum price consumers were ready to pay for the product. None of the effects were significant (Table 2).

Table 2: Means of Intention to Purchase and Willingness to Pay, the Country of Origin Effect

\begin{tabular}{l|cc}
\hline \multirow{2}{*}{ Intention to purchase $\mathbf{W U L}_{\text {thyme }}$} & Test Group: Phase 3 (Ecolabel and Country of Origin Information) \\
\cline { 2 - 3 } Willingness to pay WUL & Spain & Switzerland \\
\cline { 2 - 3 } Intention to purchase $\mathbf{W L}_{\text {Rosemary }}$ & $3,69(1,49)^{*}$ & $4,31(1,51)$ \\
Willingness to pay WUL $_{\text {Rosemary }}$ & $1,78(, 66)^{*}$ & $2,00(, 60)$ \\
& $3,64(1,61)^{*}$ & $4,30(1,55)$ \\
\hline
\end{tabular}

Standard deviations are presented in brackets

We then tested the moderating effect of consumers' socio-demographic and behavioral characteristics variables. To this end, we conducted a general multivariate linear model. The results show that among the sociodemographic variables, only the education level impacts significantly the product's assessment $(\mathrm{p}=.019)$. Moreover, the results indicate that familiarity with ecological products $(\mathrm{p}=.039)$ and trust towards the country of production $(\mathrm{p}=.006)$ have a significant effect on product's evaluation.

\section{DISCUSSION AND CONCLUSION}

Our study contributes to a better understanding of the impact of the country ecological image. The results obtained confirm that the ecological image of the country of origin may have a power of differentiation, even in the case of products presenting the same eco-quality.

From a practical point of view, the results of this study open up new applications with regard to the association between an ecolabel and country of origin. Managers could improve the combined use of different 
signals by taking into account the effects of the reinforcement and moderation of a signal generated by the presence of another (Price \& Dawar, 2002).

In the case of an ecological product produced in a country with a positive ecological image, for instance, managers would do well to mention the country of origin in addition to the ecolabel.

In the case of a country with a negative ecological image, the study offers a few ideas for reflection. For example, managers should try to increase the level of consumer confidence with regard to the product's country of origin. Delocalising part of the manufacturing process to a country with a positive ecological image may be one solution (Price \& Dawar, 2002). Another option would be to develop initiatives to make the production process more ecological at local level. Joint action to improve the products' ecological dimension (especially at the level of processes) and bringing several groups of companies together in clusters may help to improve the country's ecological image by way of a summary effect (Han, 1989).

Our findings should nonetheless be considered with some caution in view of the methodological limitations. The first limitation is the fact that the sample is not representative of the French population as a whole. Another limitation is that only one product category was tested. To strengthen the external validity of the research findings, it would be interesting to replicate the study with other products, introducing further explanatory factors such as attitude towards the product category, brand loyalty, etc.

Finally, given that the source country ecological image has still been little explored to date, it would be beneficial to study the various facets of this concept in more depth, and to determine how the assessment of an ecolabelled product is influenced by each of the dimensions arising from the ecological image of the country of origin.

\section{AUTHOR INFORMATION}

Sihem Dekhili is an associate professor of Marketing at EM Strasbourg Business School. She primarily carries out research in the field of consumer behavior, including analyzing perceived quality and the importance of origin cues. Recently, her research interests focus on responsible consumption, eco-labeling, ethics, and price fairness. Her work has been published in Journal of Business Research, European Business Review, Food Quality and Preference, Business Strategy and the Environment, amongst others. She has presented her research findings at national and international marketing conferences. Dr. Dekhili is a member of the American Marketing Association and French Marketing Association. E-mail: sihem.dekhili@em-strasbourg.eu (Corresponding author)

Mohamed Akli Achabou is an associate professor of Strategic Management at IPAG Paris Business School. Dr. Achabou's research interests embrace enterprises responsible practices and their coherence with green consumers' expectations. Dr. Achabou has published his work in several conference proceedings and in refereed academic journals including the Journal of Business Research, Journal of Multi-Criteria Decision Analysis, Business Strategy and the Environment, Business Management Review, amongst others. E-mail: ma.achabou@ipag.fr

\section{REFERENCES}

1. Chan, R. Y. K. (2000). The effectiveness of environmental advertising: The role of claim type and the source country green image. International Journal of Advertising, 19, 349-375.

2. D'Souza, C., Taghian, M., Lamb, P., Peretiatko, R. (2007). Green decisions: Demographics and consumer understanding of environmental labels. International Journal of Consumer Studies, 31(4), 371-376.

3. Fiske, S. K., Kinder, D. R., \& Larter, W. M. (1983). The novice and the expert: Knowledge-based strategies in political cognition. Journal of Experimental Social Psychology, 19, 381-400.

4. Fitzsimons, G. J. (2008). Editorial: A death to dichotomizing. Journal of Consumer Research, 35(1), 5-8.

5. Han, C. M. (1989). Country image: Halo or summary construct. Journal of Marketing Research, 34(26), 222-229.

6. Harris, J. D., \& Freeman, R. E. (2008). The impossibility of the separation thesis. Business Ethics Quarterly, 18(106), 541-548. 
7. Hong, S. T., \& Kang, D. K. (2006). Country-of-origin influences on product evaluations: The impact of animosity and perceptions of industriousness brutality on judgments of typical and atypical products. Journal of Consumer Psychology, 16 (3), 232-239.

8. Insch, G. S., \& McBride, J. B. (2004). The impact of country-of-origin cues on consumer perceptions of product quality: A binational test of the decomposed country-of-origin construct. Journal of Business Research, 57, 256-265.

9. Lozano, J., Blanco, E., \& Rey-Maquieira, J. (2010). Can ecolabels survive in the long run? The role of initial conditions. Ecological Economics, 69, 2525-2534.

10. Manrai, L. A., Manrai, A. K., Lascu, D. N., \& Ryans, J. K. (1997). How green-claim strength and country disposition affect product evaluation and company image. Psychology and Marketing, 14(5), 511-537.

11. Meyers-Levy, J., \& Tybout, A. M. (1989). Schema congruity as a basis for product evaluation. Journal of Consumer Research, 16, 39-54.

12. Nagashima, A. (1970). A comparison of Japanese and US attitudes toward foreign products. Journal of Marketing, 34, 68-74.

13. Onozaka, Y., \& Thilmany-McFadden, D. (2011). Does local labeling complement or compete with other sustainable labels? A conjoint analysis of direct and joint values for fresh produce claim. American Journal of Agricultural Economics, 93(3), 689-702.

14. Parameswaran, R., \& Yaprak, A. (1987). A cross-national comparison of consumer research measures. Journal of International Business Studies, 18, 35-49.

15. Price, L. J., \& Dawar, N. (2002). The joint effects of brands and warranties in signaling new product quality. Journal of Economic Psychology, 23, 165-190.

16. Reuber, A. R., \& Fischer, E. (2011). When nobody knows your name: Country-of-origin as a reputational signal for online businesses. Corporate Reputation Review, 14(1), 37-51.

17. Smith, A., Watkiss, P., Tewddle, G., McKinnon, A., Browne, M., Hunt, A., Trevelen, C., Nash, C., \& Cross, S. (2005). The validity of food miles as an indicator of sustainable development. London: DEFRA.

18. Thøgersen, J., Jørgensen, A. K., \& Sandager, S. (2012). Consumer decision making regarding a "green" everyday product. Psychology \& Marketing, 29(4), 187-197.

19. Thøgersen, J., Haugaard, P., \& Olesen, A. (2010). Consumer responses to ecolabels. European Journal of Marketing, 44 (11/12), 1787-1810.

20. World Economic Forum (2013), The Global Competitiveness Report. 545 p. 


\section{NOTES}

